Article

\title{
Iron-based catalysts encapsulated by nitrogen-doped graphitic carbon for selective synthesis of liquid fuels through the Fischer-Tropsch process
}

\author{
Lei Tang, Xiao-Ling Dong, Wei Xu, Lei He, An-Hui Lu* \\ State Key Laboratory of Fine Chemicals, School of Chemical Engineering, Dalian University of Technology, Dalian 116024, Liaoning, China
}

\section{A R T I C L E I N F O}

\section{Article history:}

Received 30 July 2018

Accepted 16 August 2018

Published 5 December 2018

\section{Keywords:}

Nitrogen doping

Graphitic carbon

Encapsulation

Iron-based catalyst

Fischer-Tropsch synthesis

\begin{abstract}
A B S T R A C T
Fischer-Tropsch synthesis (FTS) has the potential to be a powerful strategy for producing liquid fuels from syngas if highly selective catalysts can be developed. Herein, a series of iron nanoparticle catalysts encapsulated by nitrogen-doped graphitic carbon were prepared by a one-step pyrolysis of a ferric L-glutamic acid complex. The FeC-800 catalyst pyrolyzed at $800{ }^{\circ} \mathrm{C}$ showed excellent catalytic activity (239.4 $\mu_{\text {molco }} \mathrm{gFe}^{-1} \mathrm{~s}^{-1}$ ), high $\mathrm{C}_{5}-\mathrm{C}_{11}$ selectivity (49\%), and good stability in FTS. The high dispersion of ferric species combined with a well-encapsulated structure can effectively inhibit the migration of iron nanoparticles during the reaction process, which is beneficial for high activity and good stability. The nitrogen-doped graphitic carbon shell can act as an electron donor to the iron particles, thus promoting $\mathrm{CO}$ activation and expediting the formation of $\mathrm{Fe}_{5} \mathrm{C}_{2}$, which is the key factor for obtaining high $\mathrm{C}_{5}-\mathrm{C}_{11}$ selectivity.
\end{abstract}

(C) 2018, Dalian Institute of Chemical Physics, Chinese Academy of Sciences. Published by Elsevier B.V. All rights reserved.

\section{Introduction}

Fischer-Tropsch synthesis (FTS) has long offered a way of producing liquid fuels such as gasoline $\left(\mathrm{C}_{5}-\mathrm{C}_{11}\right)$ and diesel $\left(\mathrm{C}_{10}-\mathrm{C}_{20}\right)$ directly from syngas $\left(\mathrm{CO} / \mathrm{H}_{2}\right)$, which in turn can be derived from feedstocks such as coal, biomass, and natural gas $[1,2]$. However, the FTS products generally follow the Anderson-Schulz-Flory (ASF) distribution, which imposes a maximum selectivity for $\mathrm{C}_{5}-\mathrm{C}_{11}$ hydrocarbons of $\sim 45 \%[3,4]$. A conventional two-stage process combining FTS with a subsequent hydrotreatment or bifunctional catalysts for $\mathrm{CO}$ hydrogenation and long-chain hydrocarbon hydrocracking has been used to enhance the $\mathrm{C}_{5}-\mathrm{C}_{11}$ selectivity $[3,5]$. Tailoring the structure and active sites of the catalysts to achieve the desired selectivity is still of vital importance and remains a key chal- lenge.

Iron-based catalysts have received wide interest for FTS because of their low cost and relatively high activity toward the production of $\mathrm{C}_{5}-\mathrm{C}_{11}$ hydrocarbons over a wide temperature range [6,7]. Many efforts have been devoted to the fabrication of novel structured iron-based catalysts with the purpose of maximizing the selectivity for $\mathrm{C}_{5}-\mathrm{C}_{11}$ hydrocarbons [8,9]. It has been demonstrated that iron carbides, especially Hägg iron carbide $\left(\chi-\mathrm{Fe}_{5} \mathrm{C}_{2}\right)$, are the active phases for FTS $[10,11]$. Compared to a conventional hematite catalyst, pure-phase $\chi-\mathrm{Fe}_{5} \mathrm{C}_{2}$ nanoparticles exhibit an enhanced catalytic activity associated with a high $\mathrm{C}_{5}-\mathrm{C}_{11}$ hydrocarbon selectivity ( 35\%) [12]. It has been shown that the $\mathrm{C}-\mathrm{C}$ coupling reaction is highly sensitive to the $\mathrm{Fe}_{5} \mathrm{C}_{2}$ facet and occurs preferentially on the terrace-like $\mathrm{Fe}_{5} \mathrm{C}_{2}(510)$ surface [13]. Further, density functional theory

\footnotetext{
* Corresponding author. Tel/Fax: +86-411-84986112; E-mail: anhuilu@dlut.edu.cn

This work was supported by the National Natural Science Foundation of China (21733002, 21506077), and the Cheung Kong Scholars Program of China (T2015036).

DOI: 10.1016/S1872-2067(18)63158-4 | http://www.sciencedirect.com/science/journal/18722067 | Chin. J. Catal., Vol. 39, No. 12, December 2018
} 
(DFT) calculations have also suggested that the direct CO dissociation route is the preferred activation pathway on the $\mathrm{Fe}_{5} \mathrm{C}_{2}(510)$ surface, which generally corresponds to high FTS activity $[14,15]$. It is worth mentioning that $\mathrm{Fe}_{5} \mathrm{C}_{2}(510)$ surface with lower surface energies usually account for a large percentage of the exposed crystal facets of $\mathrm{Fe}_{5} \mathrm{C}_{2}[14,16]$. Thus, pure-phase $\mathrm{Fe}_{5} \mathrm{C}_{2}$ nanoparticle catalysts have great potential for the production of $\mathrm{C}_{5}-\mathrm{C}_{11}$ hydrocarbons. However, pure-phase $\mathrm{Fe}_{5} \mathrm{C}_{2}$ nanoparticles are not easy to obtain because either harsh synthetic conditions or complicated synthetic procedures are required, posing a potential barrier to their wide application $[12,17]$. The coexistence of abundant phases, such as $\mathrm{Fe}_{2} \mathrm{O}_{3}, \mathrm{Fe}_{3} \mathrm{O}_{4}, \varepsilon-\mathrm{Fe}_{2.2} \mathrm{C}$, and $\mathrm{Fe}_{5} \mathrm{C}_{2}$, is always ineluctable, and moreover, complicated phase transformations could occur under the reaction conditions [10]. Therefore, it is desirable to develop stable iron-based FTS catalysts containing the maximum possible $\mathrm{Fe}_{5} \mathrm{C}_{2}$ content under the reaction conditions.

Nanocarbon materials with high surface areas, rich porosities, and tunable surface chemistry are becoming attractive as supports for iron-based FTS catalysts [11,18]. In particular, graphitized nanocarbon materials, such as carbon nanotubes (CNTs) and graphene, with extended $\pi$-systems and high electron densities are able to promote the reduction of iron oxide nanoparticles, thus expediting the formation of $\mathrm{Fe}_{5} \mathrm{C}_{2}[4,19]$. Furthermore, nitrogen-doped graphitic carbon can be used as an electron donor to iron catalysts to facilitate the formation of $\mathrm{Fe}_{5} \mathrm{C}_{2}[11,20]$. Therefore, nitrogen-doped graphitic carbon shows great potential for the construction of $\mathrm{Fe}_{5} \mathrm{C}_{2}$-enriched iron-based catalysts.

The fabrication of encapsulated structures for iron-carbon catalysts can also promote the formation and stability of iron carbides, including $\mathrm{Fe}_{5} \mathrm{C}_{2}$, owing to unique spatial confinement effects $[19,21]$, and thus, the selectivity for long-chain hydrocarbons can be enhanced. For example, Bao's group [21] found that $\mathrm{Fe}_{2} \mathrm{O}_{3}$ nanoparticles encapsulated within CNTs (Fe-in-CNT) formed more iron carbides under the reaction conditions than nanoparticles outside the CNTs (Fe-out-CNT). Further, the selectivity of the Fe-in-CNT catalyst toward $\mathrm{C}_{5+}$ hydrocarbons (29\%) was 1.5 times greater than that of the Fe-out-CNT catalyst and more than 3 times greater than that of an activated-carbon-supported iron catalyst (Fe/AC). Similarly, Yu et al. [22] demonstrated that iron oxides embedded in carbon spheres with high dispersion produce a higher content of iron carbides and yield a $\mathrm{C}_{5}-\mathrm{C}_{12}$ selectivity of $40 \%$. As a working hypothesis, the combination of nitrogen-doped graphitic carbon and an encapsulated structure may take full advantage of the electronic and confinement effects to produce an iron-based catalyst with a high content of $\mathrm{Fe}_{5} \mathrm{C}_{2}$ toward high $\mathrm{C}_{5}-\mathrm{C}_{11}$ hydrocarbon selectivity.

Herein, a series of iron-based catalysts encapsulated by nitrogen-doped graphitic carbon were synthesized by a one-step pyrolysis of a ferric L-glutamic acid complex. The encapsulation structure was further adjusted by varying the pyrolysis temperature. The combination of highly dispersed ferric species and a nitrogen-doped graphitic carbon encapsulation structure provided the as-prepared catalysts with good activity, high $\mathrm{C}_{5}-\mathrm{C}_{11}$ selectivity, and excellent stability in FTS.

\section{Experimental}

\subsection{Catalyst preparation}

The complex was prepared by coordination of ferric chloride and L-glutamic acid with the aim of obtaining highly dispersed iron species. Briefly, $6.85 \mathrm{mmol}$ of L-glutamic acid was first dissolved in $50 \mathrm{~mL}$ of deionized water at $60{ }^{\circ} \mathrm{C}$ to form a clear solution, and then $0.62 \mathrm{mmol}$ of $\mathrm{FeCl}_{3} \cdot 6 \mathrm{H}_{2} \mathrm{O}$ was added under vigorous stirring. Subsequently, the mixed solution was kept at $80{ }^{\circ} \mathrm{C}$ under stirring until the water was evaporated. The resultant complex was then pyrolyzed at 700,800 , or 900 ${ }^{\circ} \mathrm{C}$ for $1 \mathrm{~h}$ under a continuous Ar flow with a heating rate of $2{ }^{\circ} \mathrm{C}$ $\min ^{-1}$. The prepared catalysts were denoted as $\mathrm{FeC}-x$, where $x$ is the pyrolysis temperature of 700,800 , or $900{ }^{\circ} \mathrm{C}$.

\subsection{Catalyst characterization}

Thermogravimetric (TG) analyses were conducted on an STA $449 \mathrm{~F} 3$ (NETZSCH) TG analyzer with a heating rate of $10^{\circ} \mathrm{C}$ $\mathrm{min}^{-1}$ to $850^{\circ} \mathrm{C}$ in flowing air. Regardless of the phase composition, all iron species should be oxidized into $\mathrm{Fe}_{2} \mathrm{O}_{3}$ after combustion in air, and this assumption was used to estimate the $\mathrm{Fe}$ contents of the catalysts. Notably, the catalytic activity of FeC- $x$ catalyst is expressed as the Fe time yield (FTY), which was calculated based on the evaluated Fe content. X-ray powder diffraction (XRD) patterns were recorded on a PANalytical X'Pert ${ }^{3}$ Powder diffractometer using $\mathrm{Cu} K_{\alpha}$ radiation $(\lambda=0.15406 \mathrm{~nm})$. The tube voltage was $40 \mathrm{kV}$ and the current was $40 \mathrm{~mA}$. Raman measurements were performed on a DXR microscope Raman spectrometer. Nitrogen adsorption isotherms were measured using a Micromeritics Tristar 3000 physisorption analyzer at $-196^{\circ} \mathrm{C}$. Prior to analysis, all samples were degassed at $200{ }^{\circ} \mathrm{C}$ for $4 \mathrm{~h}$. The specific surface areas $\left(A_{\mathrm{BET}}\right)$ were calculated from the adsorption data in the relative pressure range 0.05-0.3 using the Brunauer-Emmett-Teller (BET) method, and the total pore volume $\left(V_{\text {total }}\right)$ was calculated using the adsorbed capacity at $P / P_{0}=0.90$. Transmission electron microscopy (TEM) images were recorded with a Tecnai F30 instrument operated at $300 \mathrm{kV}$. X-ray photoelectron spectra (XPS) analyses were conducted with a Thermo VG ESCALAB 250 Microprobe instrument. The corresponding binding energies of the elements were calibrated using the $\mathrm{C} 1 s$ photoelectron peak at $284.6 \mathrm{eV}$. Temperature-programmed reduction of hydrogen $\left(\mathrm{H}_{2}\right.$-TPR) was performed on a Micromeritics AutoChem II 2920 apparatus with a thermal conductivity detector (TCD) by passing $8 \% \mathrm{H}_{2} /$ Ar over $50 \mathrm{mg}$ of sample at a heating rate of $10^{\circ} \mathrm{C} \mathrm{min}-1$ to $750{ }^{\circ} \mathrm{C}$. Before each measurement, the sample was pretreated at $150{ }^{\circ} \mathrm{C}$ for $30 \mathrm{~min}$ under an Ar flow to ensure a clean surface. Temperature-programmed desorption of carbon monoxide (CO-TPD) was performed on a Micromeritics AutoChem II 2920 apparatus. Typically, $100 \mathrm{mg}$ of sample was pretreated in flowing $8 \% \mathrm{H}_{2} / \mathrm{Ar}$ at $400{ }^{\circ} \mathrm{C}$ for $2 \mathrm{~h}$. Subsequently, the catalyst was cooled to $50{ }^{\circ} \mathrm{C}$ and the gas was then switched to flowing He to flush the apparatus. CO adsorption was achieved by flowing $5 \% \mathrm{CO} / \mathrm{He}$ for $30 \mathrm{~min}$, and the system was then purged with flowing He for another $30 \mathrm{~min}$. Then, the sample was 
heated at a rate of $10{ }^{\circ} \mathrm{C} \mathrm{min}-1$ to $800{ }^{\circ} \mathrm{C}$ in flowing He. The gas exiting the reactor was analyzed with a TCD.

\subsection{Catalytic reaction}

The FTS reactions were conducted in a tubular fixed-bed reactor (inner diameter: $8 \mathrm{~mm}$ ) operating at a total pressure of 20 bar, $300{ }^{\circ} \mathrm{C}$, and a $\mathrm{H}_{2} / \mathrm{CO} / \mathrm{Ar}$ ratio of $64: 32: 4$ (by volume). Prior to $\mathrm{CO}$ hydrogenation, each catalyst $(100 \mathrm{mg})$ was activated under a flow of $\mathrm{H}_{2}\left(30 \mathrm{~mL} \mathrm{~min}^{-1}\right)$ over $5 \mathrm{~h}$ at atmospheric pressure and $400{ }^{\circ} \mathrm{C}$. After the activation period, the reactor temperature was cooled to $250^{\circ} \mathrm{C}$ under flowing hydrogen and then a flow of premixed syngas $\left(20 \mathrm{~mL} \mathrm{~min}^{-1}\right)$ was gradually introduced into the reactor. Subsequently, the temperature was slowly increased to $300{ }^{\circ} \mathrm{C}$ at a rate of $2{ }^{\circ} \mathrm{C} \mathrm{min}^{-1}$ when the total pressure reached 20 bar. The effluents were introduced in a gaseous state at a temperature of $240{ }^{\circ} \mathrm{C}$ and analyzed quantitatively with an online gas chromatograph (GC-9160) equipped with a TCD and a flame-ionization detector (FID). Ar, $\mathrm{CO}, \mathrm{CH}_{4}$, and $\mathrm{CO}_{2}$ were analyzed with a TDX-01 packed column connected to the TCD. A PONA capillary column connected to the FID was used to analyze hydrocarbons $\left(\mathrm{C}_{1}-\mathrm{C}_{30}\right)$. The $\mathrm{CO}$ conversion was calculated by an internal normalization method using Ar as an internal standard gas. The hydrocarbon selectivity was calculated on a molar carbon basis. The catalytic performances after FTS over $20 \mathrm{~h}$ on stream were used for discussion.

\section{Results and discussion}

The FTS performances of the $\mathrm{FeC}-x$ catalysts were investigated at $300{ }^{\circ} \mathrm{C}$ and 20 bar. As shown in Fig. 1 and Table 1, the FeC-800 catalyst exhibited a CO conversion of $47 \%$, which was much higher than those for FeC-700 (12\%) and FeC-900 (3\%). Notably, there was no obvious induction period for FeC-800, and a steady performance was observed over a prolonged reaction time of $60 \mathrm{~h}$. Remarkably, the FTY value (the number of CO moles converted to hydrocarbons per gram of iron per second) of FeC-800 was calculated to be $239.4 \mu$ molco $_{\mathrm{Fe}^{-1}} \mathrm{~s}^{-1}$, which was two times that of FeC-700 (106.3 $\mu$ molco $\left.\mathrm{gFe}^{-1} \mathrm{~s}^{-1}\right)$ and twenty times that of FeC-900 $\left(12.5 \mu\right.$ mol $\left._{\mathrm{Co}} \mathrm{g}_{\mathrm{Fe}}{ }^{-1} \mathrm{~s}^{-1}\right)$. The selectivities toward long-chain $\left(\mathrm{C}_{5+}\right)$ hydrocarbons were $52 \%$ for FeC-800 and $49 \%$ for FeC-700. In particular, the selectivities for gasoline-range hydrocarbons $\left(\mathrm{C}_{5}-\mathrm{C}_{11}\right)$ were $49 \%$ for $\mathrm{FeC}-800$ and $46 \%$ for $\mathrm{FeC}-700$, which were better than those for reported iron-carbon catalysts such as Fe-in-CNT, Fe-out-CNT, Fe/AC, and Fe@C spheres [21,22]. Interestingly, the selectivity toward $\mathrm{C}_{5+}$ hydrocarbons was $15 \%$ for $\mathrm{FeC}-900$, which implies that the structure of the FeC- $x$ catalysts was significantly changed by adjusting the pyrolysis temperature.

To identify the origin of the observed variation in catalytic performance of the FeC- $x$ catalysts, a series of physicochemical analyses were performed. The TEM images (Fig. 2) of the $\mathrm{FeC}-x$ catalysts showed that the iron nanoparticles were highly dispersed in the carbon matrix. The high-resolution TEM images
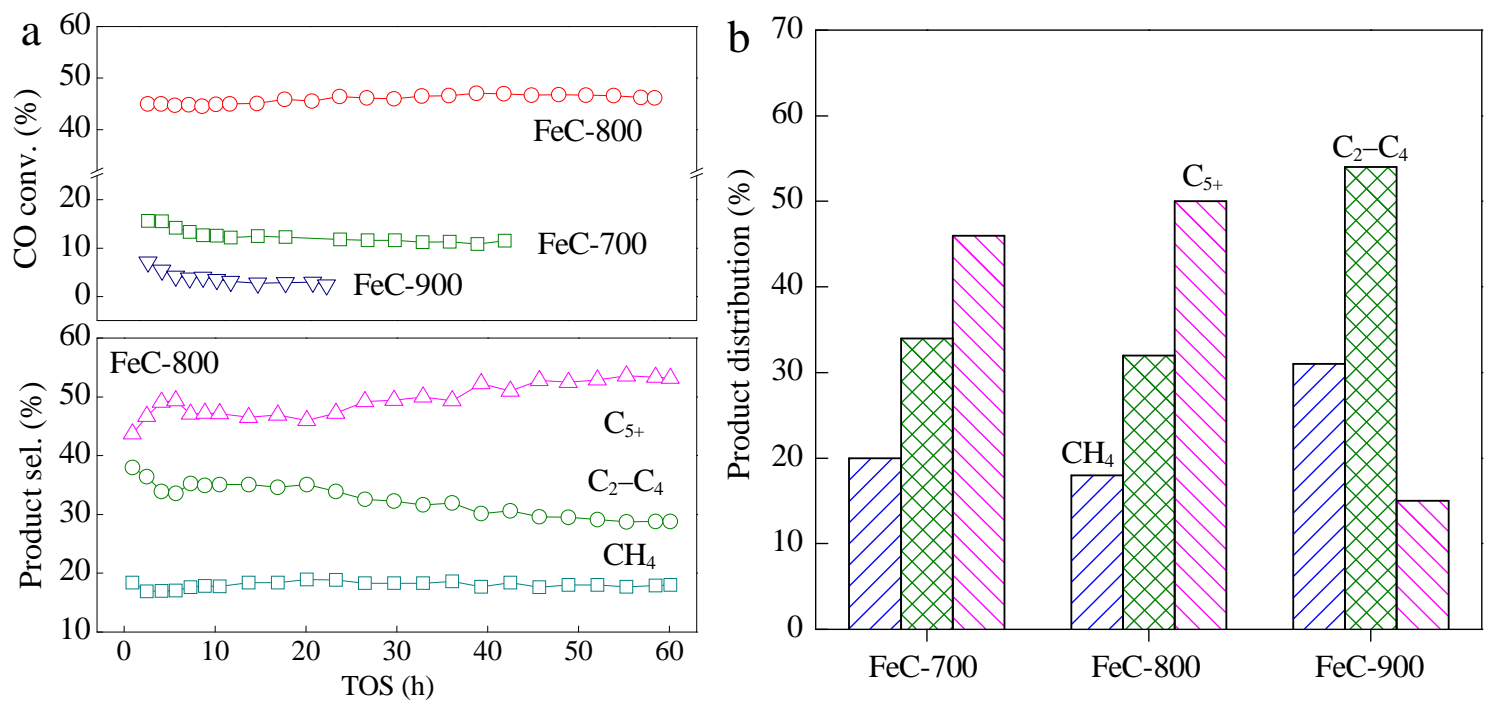

Fig. 1. CO conversion and selectivity with time on stream (TOS) (a) and representative catalytic performance after FTS over 20 h (b) of the FeC- $x$ catalysts. Reaction conditions: $100 \mathrm{mg}$ of catalyst, $\mathrm{H}_{2} / \mathrm{CO} / \mathrm{Ar}=64: 32: 4,20 \mathrm{~mL} \mathrm{~min}^{-1}, 20 \mathrm{bar}, 300^{\circ} \mathrm{C}$.

Table 1

Representative catalytic performance after FTS over $20 \mathrm{~h}$.

\begin{tabular}{|c|c|c|c|c|c|c|c|}
\hline \multirow{2}{*}{ Sample } & \multirow{2}{*}{$\begin{array}{c}\text { CO conv. } \\
(\%)\end{array}$} & \multirow{2}{*}{$\begin{array}{c}\text { FTY } \\
\left(\mu \text { mol }_{\mathrm{Co}} \mathrm{g}_{\mathrm{Fe}}{ }^{-1} \mathrm{~s}^{-1}\right)\end{array}$} & \multicolumn{4}{|c|}{$\mathrm{C}_{m} \mathrm{H}_{n}$ sel. $(\%)$} & \multirow{2}{*}{$\begin{array}{c}\mathrm{CO}_{2} \text { sel. } \\
(\%)\end{array}$} \\
\hline & & & $\mathrm{CH}_{4}$ & $\mathrm{C}_{2}-\mathrm{C}_{4}$ & $\mathrm{C}_{5+}$ & $\mathrm{C}_{5}-\mathrm{C}_{11}$ & \\
\hline $\mathrm{FeC}-700$ & 12 & 106.3 & 20 & 34 & 46 & 46 & 10 \\
\hline FeC-800 & 47 & 239.4 & 18 & 30 & 52 & 49 & 24 \\
\hline FeC-900 & 3 & 12.5 & 31 & 54 & 15 & 15 & 16 \\
\hline
\end{tabular}

Reaction conditions: $100 \mathrm{mg}$ of catalyst, $\mathrm{H}_{2} / \mathrm{CO} / \mathrm{Ar}=64: 32: 4,20 \mathrm{~mL} \mathrm{~min}^{-1}, 20 \mathrm{bar}, 300{ }^{\circ} \mathrm{C}$. 
(Fig. 2) indicated that the iron nanoparticles were mostly encapsulated by a few graphitic carbon layers. As shown in Fig. S1 (Supporting Information), the graphitic carbon layers encapsulated holes in acid-treated FeC-800 catalysts, further demonstrating that the iron particles were tightly encapsulated by the graphitic carbon layers. Amino acids have a strong tendency to coordinate with metal cations owing to their abundant functional groups, such as $-\mathrm{NH}_{2}$ and $-\mathrm{COOH}$. The advantage of using L-glutamic acid as a carbon precursor is that the ferric ion can be homogeneously distributed at the molecular level in the ferric L-glutamic acid complex and subsequently form highly dispersed nanoparticles during the pyrolysis process [23]. Besides, graphite is favorably generated on the surface of iron nanoparticles because of the small lattice mismatch [24]. This process possibly expedites the formation of the graphitic carbon shell and the encapsulated structure.

According to the TG curves in air (Fig. 3(a)), regardless of the phase composition, all the iron species should be oxidized to $\mathrm{Fe}_{2} \mathrm{O}_{3}$ after combustion in air, which allowed the $\mathrm{Fe}$ content in the catalysts to be estimated [25]. Using this method, the
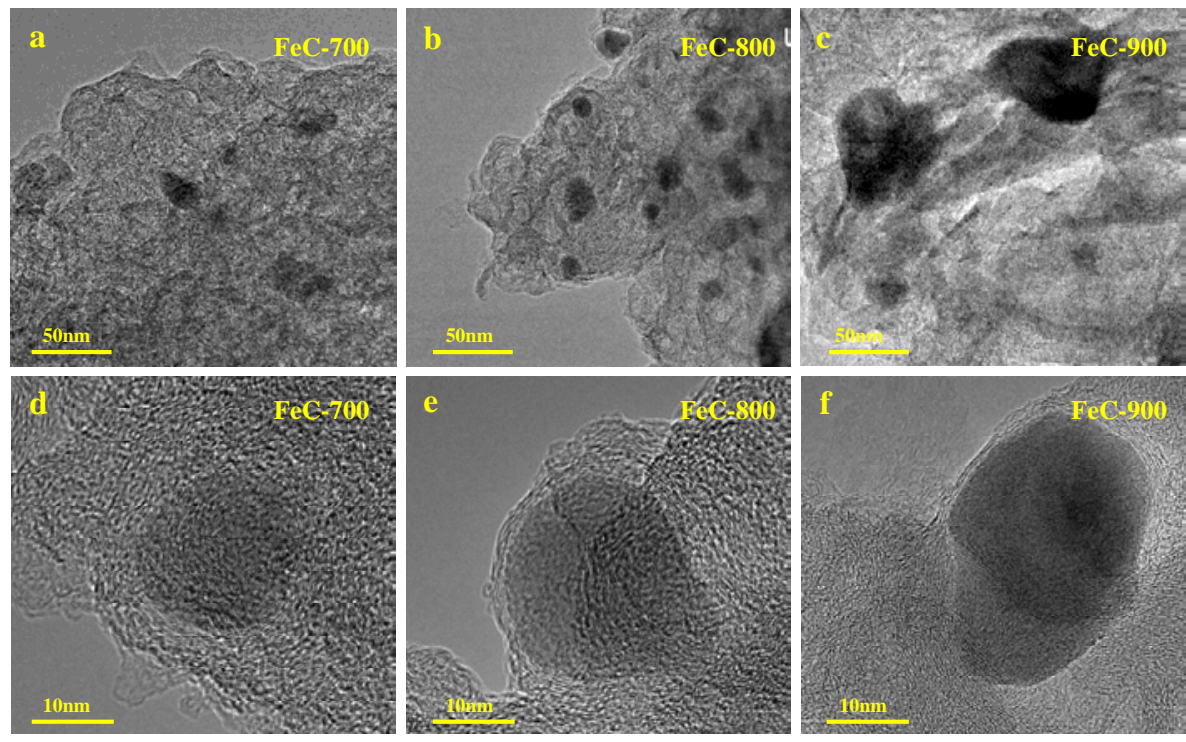

Fig. 2. TEM images (a, b, c) and high-resolution TEM images (d, e, f) of the FeC- $x$ catalysts.
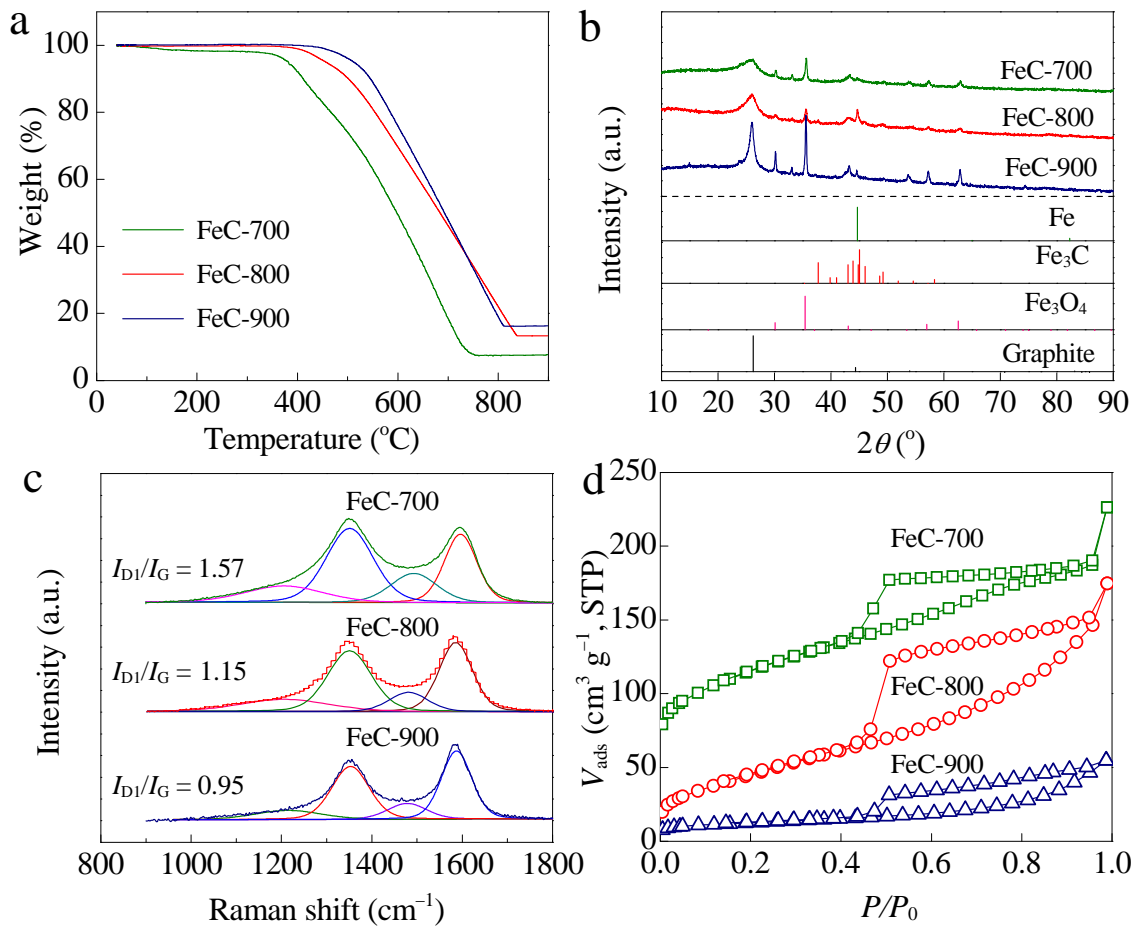

Fig. 3. TG curves in air (a), XRD patterns (b), Raman spectra (c), and $\mathrm{N}_{2}$ sorption isotherms (d) of the FeC- $x$ catalysts. Note that the $\mathrm{N}_{2}$ sorption isotherm of FeC-800 is offset vertically by $-30 \mathrm{~cm}^{3} \mathrm{~g}^{-1}$ at STP. 
contents of $\mathrm{Fe}_{2} \mathrm{O}_{3}$ were found to be $7.7 \mathrm{wt} \%$ for $\mathrm{FeC}-700,13.4$ wt $\%$ for FeC-800, and 16.3 wt $\%$ for FeC-900, and the corresponding iron contents were 5.4, 9.4, and $11.4 \mathrm{wt} \%$ (Table 2). As shown in the XRD patterns (Fig. 3(b)), the main peaks at $30.1^{\circ}, 35.4^{\circ}, 43.1^{\circ}, 57.0^{\circ}$, and $62.5^{\circ}$ were assigned to the $\mathrm{Fe}_{3} \mathrm{O}_{4}$ phase (COD: 01-089-3854). Further, the peak observed at $44.7^{\circ}$ for FeC-800 and FeC-900 was attributed to metallic iron (COD: 03-065-4899), suggesting that the reduction of $\mathrm{Fe}_{3} \mathrm{O}_{4}$ was facilitated by increasing the pyrolysis temperature. Moreover, the overlapping peaks located at approximately $43^{\circ}$ indicated the presence of $\theta-\mathrm{Fe}_{3} \mathrm{C}$ (COD: 00-006-0688). The peak at $26.2^{\circ}$ was assigned to the (002) plane of graphitic carbon (COD: 01-075-1621). This peak became sharper as the pyrolysis temperature increased, indicating a higher graphitization degree.

Raman measurements were conducted to further probe the structures of the FeC- $x$ catalysts. As shown in Fig. 3(c), the G-band at $1587 \mathrm{~cm}^{-1}$ was assigned to the stretching vibration of $\mathrm{C}=\mathrm{C}$ bonds in typical graphitic layers, which strongly indicated the formation of a graphitic framework [26]. The graphitization degree can be characterized by the ratio of the integrated intensities for the D- and G-bands $\left(I_{\mathrm{D} 1} / I_{\mathrm{G}}\right)$. The calculated $I_{\mathrm{D} 1} / I_{\mathrm{G}}$ ratio for FeC-900 was approximately 0.95, which was lower than those for FeC-700 (1.57) and FeC-800 (1.15). This result demonstrates the higher graphitization degree of FeC-900 and is consistent with the XRD results.

The $\mathrm{N}_{2}$ physisorption measurements (Fig. 3(d)) indicated that the catalysts had typical mesoporous structures, as the curves exhibited typical type IV isotherms and $\mathrm{H}_{2}$ hysteresis loops. Such a mesoporous structure is beneficial for the diffusion of the reactants and products. The specific surface areas ( $\left.A_{\mathrm{BET}}\right)$ of FeC-700, FeC-800, and FeC-900 were 387, 258, and 43 $\mathrm{m}^{2} \mathrm{~g}^{-1}$, respectively (Table 2). The decrease of AвEт with the increase in the pyrolysis temperature was mainly caused by increased graphitization of the carbon materials, which resulted in a sacrifice of microporosity [27]. This finding is in line with the XRD and Raman data.

The XPS spectra (Fig. 4(a)) revealed that C, O, N, and Fe were the primary surface species. The surface Fe atomic compositions were $0.9 \%, 0.8 \%$, and $0.1 \%$ for FeC-700, FeC-800, and FeC-900, respectively (Table S1). Compared to the iron contents of FeC- $x$ calculated by TG analysis, the low Fe contents detected on the surface suggested that most iron particles were covered by a carbon shell. The C $1 s$ XPS spectra (Fig. 4(b) and Fig. S2) were deconvoluted into different components that correspond to carbon atoms in different chemical environments [28,29]. The main C $1 s$ peak located at $284.6 \mathrm{eV}$ was assigned to $s p^{2}$-hybridized carbon atoms on the graphitic surface, indicating the predominant existence of graphite in these ma-

Table 2

Structural parameters of the FeC- $x$ catalysts.

\begin{tabular}{lcccc}
\hline Sample & $\begin{array}{c}A_{\text {BET }} \\
\left(\mathrm{m}^{2} \mathrm{~g}^{-1}\right)\end{array}$ & $\begin{array}{c}V_{\text {total }} \\
\left(\mathrm{cm}^{3} \mathrm{~g}^{-1}\right)\end{array}$ & $\begin{array}{c}\text { Average pore } \\
\text { diameter }(\mathrm{nm})\end{array}$ & $\begin{array}{c}\text { Iron content } \\
(\mathrm{wt} \%)\end{array}$ \\
\hline FeC-700 & 387 & 0.35 & 3.9 & 5.4 \\
FeC-800 & 258 & 0.32 & 4.0 & 9.4 \\
FeC-900 & 43 & 0.08 & 3.7 & 11.4 \\
\hline
\end{tabular}

terials. The small peak at $285.6 \mathrm{eV}$ was related to surface C-N bonds, whereas the peaks at 286.3 and $287.5 \mathrm{eV}$ were attributed to $\mathrm{C}-\mathrm{O}$ and $\mathrm{C}=\mathrm{O}$ bond, respectively. Furthermore, other minor peaks indicated the presence of $\mathrm{O}-\mathrm{C}=\mathrm{O}(288.8 \mathrm{eV})$ and the typical $\pi-\pi^{*}$ shakeup lines of graphite and graphite-like compounds $(\sim 290.2$ and $292.2 \mathrm{eV})$. The presence of functional surface groups results in the formation of defects in graphite-like nanostructures [29]. Therefore, as shown in Table S2, a higher concentration of $s p^{2}$-hybridized surface carbon atoms suggests a higher graphitization degree. The Fe $2 p$ peaks of FeC-700 and FeC-800 appeared at $\sim 711.5 \mathrm{eV}\left(\mathrm{Fe} 2 p_{3 / 2}\right)$ and $\sim 724.5 \mathrm{eV}(\mathrm{Fe}$ $2 p_{1 / 2}$ ), which are characteristic of $\mathrm{Fe}^{3+}$ (Fig. 4(c)) [30]. Specifically, the appearance of the $\mathrm{Fe}^{3+} 2 p_{3 / 2}$ peaks at approximately $711.5 \mathrm{eV}$, which was somewhat higher in energy than the peak at $710.8 \mathrm{eV}$ for $\mathrm{Fe}_{2} \mathrm{O}_{3}$, suggested the existence of $\mathrm{Fe}_{3} \mathrm{O}_{4}$ species in the catalysts [11]. This finding is in agreement with the XRD results (Fig. 3(a)). As depicted in Fig. 4(d), N 1s peaks were observed near 398.4, 399.6, and $401.0 \mathrm{eV}$, which were related to N-6 (pyridinic N), N-5 (pyrrolic N), and N-Q (graphitic N) carbon-nitrogen bonding configurations [31]. In the FeC-900 catalyst, the higher $\mathrm{N}-\mathrm{Q}$ concentration accompanied by the lower nitrogen content originated from the higher pyrolysis temperature (Table S2). This finding demonstrates that the nitrogen atoms are doped into the graphitic carbon matrix.

The combined evidence indicated that catalysts consisting of iron nanoparticles encapsulated by nitrogen-doped graphitic carbon were prepared by the pyrolysis of a ferric L-glutamic acid complex. The confinement effects of the encapsulated structure can effectively inhibit the migration of iron nanoparticles, which endows the FeC- $x$ catalysts with excellent stability during the reaction process (Fig. 1(a)). Remarkably, even after a reaction of over $60 \mathrm{~h}$, the mean sizes of the iron particles in the spent FeC-800 catalyst $(28.4 \mathrm{~nm})$ remained similar to those of the catalyst prior to reaction $(28.8 \mathrm{~nm})$, suggesting excellent stability (Fig. S3). In contrast, removal of the carbon shell of FeC-800 by calcination at $300{ }^{\circ} \mathrm{C}$ in air led to the aggregation of the iron nanoparticles and this catalyst gave only $4 \%$ conversion in FTS (Fig. S4). This result further indicates the stabilizing effect of the carbon shell on the iron nanoparticles.

Although the ASF distribution places limitations on the ratio of a certain product, it has been proved changeable by optimizing several factors, such as the promoter, the core-shell structure, and the microenvironment of the active metal $[18,22,32]$. The structure of the carbon shell is one of the factors that influence the FTS product distribution. Compared to traditional supported $\mathrm{Fe} / \mathrm{C}$ catalysts, a carbon shell hinders gas diffusion and leads to a high selectivity for hydrocarbons with less than twelve carbon atoms [33]. Meanwhile, a carbon shell restricts the diffusive removal of reactive olefins, which can undergo further reactions to grow into longer-chain hydrocarbons [34]. Consequently, a carbon shell with an appropriate thickness and a porous structure is beneficial for obtaining $\mathrm{C}_{5}-\mathrm{C}_{11}$ hydrocarbons. In our work, the thickness of the carbon shell decreased with the increase in the pyrolysis temperature. Appropriate thickness of the carbon shell may contribute to the high selectivities of $\mathrm{FeC}-700$ and $\mathrm{FeC}-800$ for $\mathrm{C}_{5}-\mathrm{C}_{11}$ hydrocarbons. The ability to selectively obtain a certain type of product in FTS by 

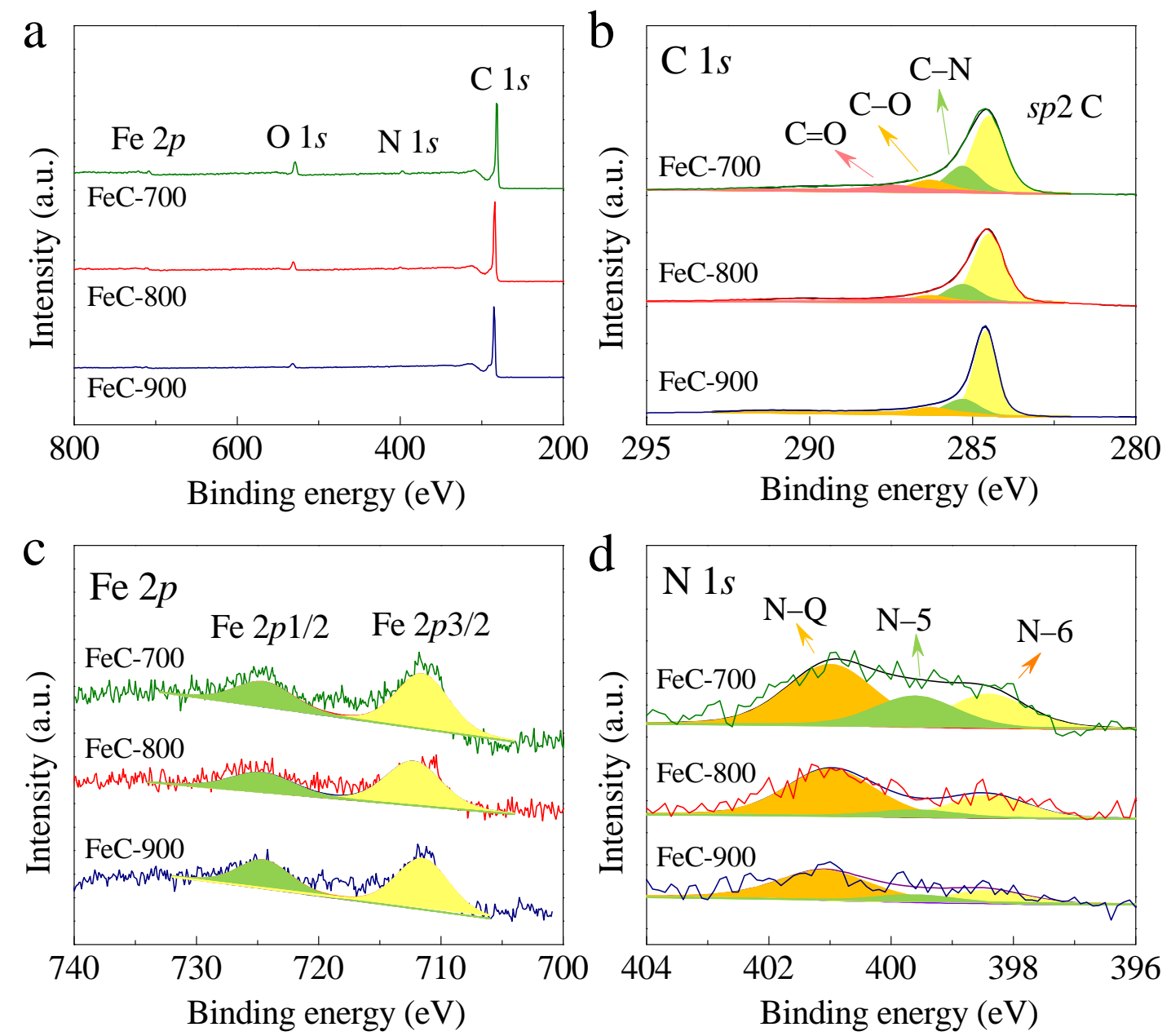

Fig. 4. XPS spectra of the FeC- $x$ catalysts. (a) Survey scan; (b) C $1 s$; (c) Fe $2 p$; (d) N $1 s$.

adjusting the structure of the catalyst is quite important.

The reduction behavior of the $\mathrm{FeC}-x$ catalysts in a $\mathrm{H}_{2}$ atmosphere was investigated by $\mathrm{H}_{2}$-TPR (Fig. 5(a)). FeC-700 exhibited four major peaks of hydrogen consumption at 297, 416, 457 , and $569^{\circ} \mathrm{C}$. The peaks below $500^{\circ} \mathrm{C}$ were attributed to the following consecutive reduction steps: $\mathrm{Fe}_{2} \mathrm{O}_{3} \rightarrow \mathrm{Fe}_{3} \mathrm{O}_{4} \rightarrow \mathrm{FeO} \rightarrow$ Fe [35]. Meanwhile, the broad peak at $569^{\circ} \mathrm{C}$ was assigned to methanation of the carbon shell in the presence of metallic $\mathrm{Fe}$, which has also been observed by others [36]. In the case of FeC-900, the reduction peaks shifted to higher temperatures, indicating the hard reducibility of the iron phases. CO-TPD was used to study the effects of the nitrogen-doped graphitic carbon shell on the $\mathrm{CO}$ adsorption behaviors. As shown in Fig. 5(b), a broad peak appeared in the range $400-600{ }^{\circ} \mathrm{C}$, which was attributed to the dissociative adsorption of $\mathrm{CO}$ on the surface of the catalysts [37]. The $\mathrm{CO}$ desorption temperature for FeC-900 $\left(\sim 540{ }^{\circ} \mathrm{C}\right)$ was higher than those for FeC-700 $\left(435{ }^{\circ} \mathrm{C}\right)$ and FeC-800 $\left(475^{\circ} \mathrm{C}\right)$, indicating a stronger interaction between iron and CO. Previous studies have shown that an electron can be transferred from nitrogen to the empty $3 d$ orbital of iron, thus strengthening the $\mathrm{Fe}-\mathrm{C}$ bond and weakening the $\mathrm{C}-\mathrm{O}$ bond
[11]. Moreover, the $p_{z}$ orbitals of graphitic carbon ( $\pi$-bonded states) can also hybridize strongly with the $d$ orbitals of iron [38]. Thus, increased graphitization of carbon materials will lead to better electron conductivity, which will facilitate electron transfer between the iron species and CO [39]. Consequently, the nitrogen-doping and higher graphitization degree of the carbon shell enhanced the CO dissociative adsorption. Additionally, $\mathrm{CO}$ activation on the catalyst surface following the direct $\mathrm{CO}$ dissociation route generally corresponds to a high $\mathrm{CO}$ hydrogenation activity [14]. However, simultaneously, the activity of $\mathrm{CO}$ hydrogenation versus the binding strength of $\mathrm{C}$ and 0 atoms on the surface generally shows a volcano curve [40]. DFT results suggest that too strong a binding strength will suppress the activity of $\mathrm{CO}$ hydrogenation [41]. Therefore, this implies that the moderate binding strength endows FeC-800 with a high activity, whereas the low activity of FeC-900 may be caused by the irreversible adsorption of $\mathrm{CO}$.

The FeC- $x$ catalysts before and after the reaction were characterized by XRD to study the phase transformations. Before the FTS reaction, the catalysts were reduced at $400{ }^{\circ} \mathrm{C}$ for $5 \mathrm{~h}$. As shown in Fig. 5(c), the initial iron oxides and iron carbides 

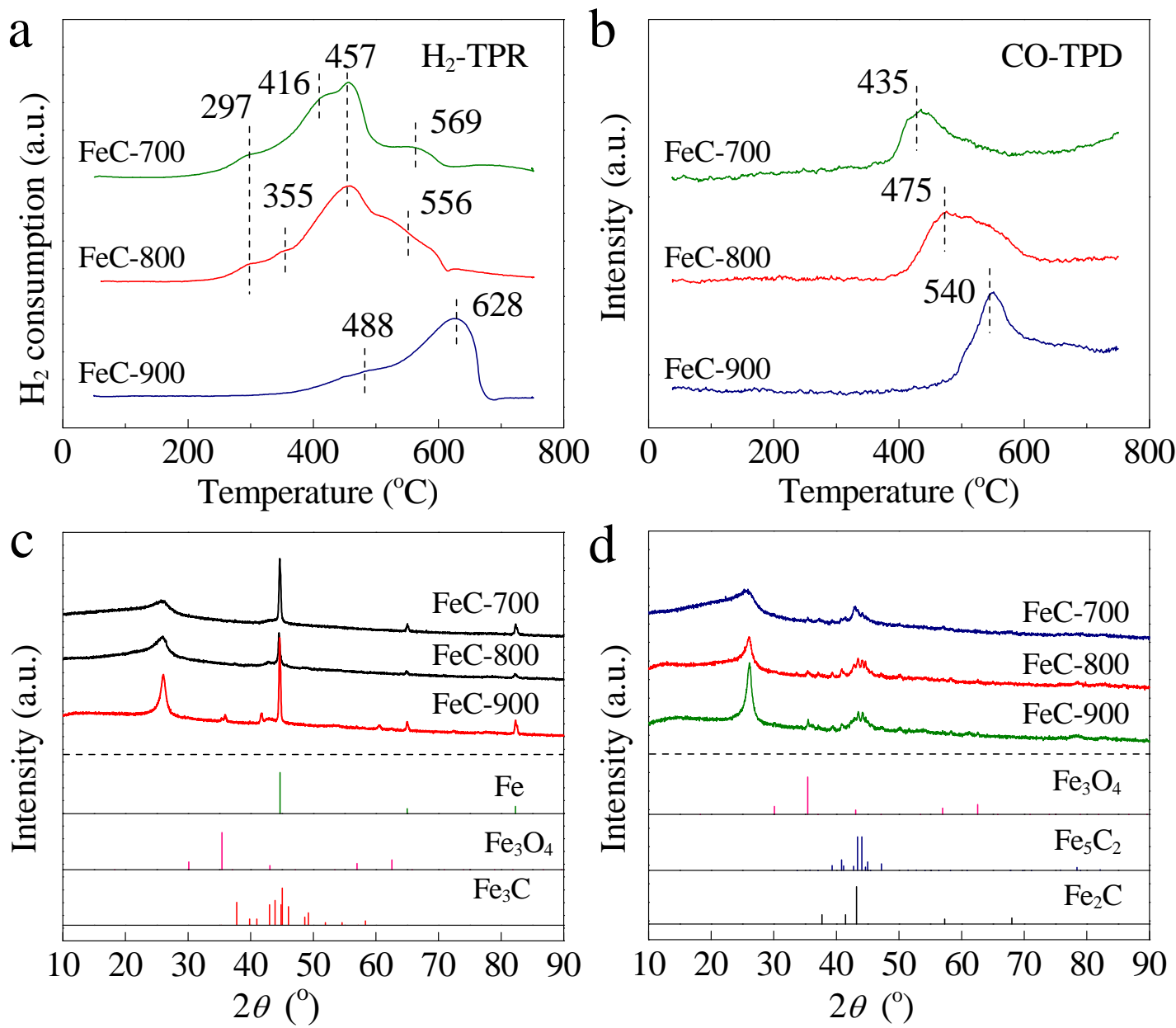

Fig. 5. $\mathrm{H}_{2}$-TPR profiles (a), CO-TPD profiles (b), XRD patterns after reduction at $400{ }^{\circ} \mathrm{C}$ for $5 \mathrm{~h}$ (c), and XRD patterns after FTS over $20 \mathrm{~h}(\mathrm{~d})$ of the FeC- $x$ catalysts.

mainly were transformed into metallic iron after reduction. The reduced $\mathrm{FeC}-900$ catalyst still exhibited the $\mathrm{Fe}_{3} \mathrm{O}_{4}$ peaks, suggesting a hard reducibility as shown in the $\mathrm{H}_{2}$-TPR profile (Fig. 5(a)). Upon exposure of the reduced catalysts to syngas, the enhanced CO dissociative adsorption ability can increase the carburization rate of the iron catalysts [42]. As shown in Fig. 1(a), a short induction period was observed to approach the steady state, suggesting that the nitrogen-doped graphitic carbon shell expedites the formation of the active phases. After FTS over $20 \mathrm{~h}$, the main iron-containing phases in the catalysts were iron carbides (Fig. 5(d)). The overlapping peaks near $43^{\circ}$ for FeC-700 suggested that $\mathrm{Fe}_{5} \mathrm{C}_{2}$ and $\mathrm{Fe}_{2} \mathrm{C}$ (COD: 00-036-1249) were the mostly likely carbides. Specifically, the actual phases identified for $\mathrm{FeC}-800$ and $\mathrm{FeC}-900$ were mainly $\mathrm{Fe}_{5} \mathrm{C}_{2}$, suggesting that the nitrogen-doped graphitic carbon shell promoted the formation of $\mathrm{Fe}_{5} \mathrm{C}_{2}$ during FTS because of the enhanced interaction between iron and CO [43]. As expected, the high content of $\mathrm{Fe}_{5} \mathrm{C}_{2}$ endowed the $\mathrm{FeC}-800$ catalyst with the ability to grow longer chain hydrocarbons and a higher FTS activity than the FeC-700 catalyst. However, despite its relatively high content of $\mathrm{Fe}_{5} \mathrm{C}_{2}$, the $\mathrm{FeC}-900$ catalyst exhibited a high selectivity toward $\mathrm{CH}_{4}$ and $\mathrm{C}_{2}-\mathrm{C}_{4}$ hydrocarbons. This behavior was possibly due to the irreversible adsorption of $\mathrm{CO}$, which decreased the probability of chain growth.

\section{Conclusions}

Iron-based catalysts encapsulated by nitrogen-doped graphitic carbon were synthesized for FTS to investigate the effects of the nitrogen-doped graphitic carbon shell on catalytic performance. The findings suggested that the confinement effects effectively inhibited the migration of highly dispersed iron nanoparticles, which endowed the catalysts with excellent stability during the reaction process. The doped nitrogen atoms and the graphitization degree of the carbon shell tailored the electronic structure to enhance the interaction between iron and CO. This structure expedited the formation of $\mathrm{Fe}_{5} \mathrm{C}_{2}$ during FTS, giving catalysts with high activities and $\mathrm{C}_{5}-\mathrm{C}_{11}$ hydrocarbon selectivities. In general, it was verified that encapsulation of iron-based catalysts by nitrogen-doped graphitic carbon results in superior FTS performance, which provides an alternative choice for the fabrication of iron-based catalysts with 
high catalytic activities and selectivities for fuel hydrocarbons.

\section{References}

[1] A. Y. Khodakov, W. Chu, P. Fongarland, Chem. Rev., 2007, 107, 1692-1744.

[2] E. F. Sousa-Aguiar, F. B. Noronha, A. Faro Jr, Catal. Sci. Technol., 2011, 1, 698-731.

[3] J. C. Kang, K. Cheng, L. Zhang, Q. H. Zhang, J. S. Ding, W. Q. Hua, Y. C. Lou, Q. G. Zhai, Y. Wang, Angew. Chem. Int. Ed., 2011, 50, 5200-5203.

[4] K. Xu, B. Sun, J. Lin, W. Wen, Y. Pei, S. R. Yan, M. H. Qiao, X. X. Zhang, B. N. Zong, Nat. Commun., 2014, 5, 5783.

[5] X. B. Peng, K. Cheng, J. C. Kang, B. Gu, X. Yu, Q. H. Zhang, Y. Wang, Angew. Chem. Int. Ed., 2015, 54, 4553-4556.

[6] Q. H. Zhang, J. C. Kang, Y. Wang, ChemCatChem, 2010, 2, 1030-1058.

[7] S. O. Moussa, L. S. Panchakarla, M. Q. Ho, M. S. El-Shall, ACS Catal., 2014, 4, 535-545.

[8] Y. L. Zhang, L. L. Ma, T. J. Wang, X. J. Li, Fuel, 2016, 177, 197-205.

[9] W. P. Ma, G. Jacobs, U. M. Graham, B. H. Davis, Top. Catal., 2014, 57, 561-571.

[10] Q. Chang, C. H. Zhang, C. W. Liu, Y. X. Wei, A. V. Cheruvathur, A. I. Dugulan, J. W. Niemantsverdriet, X. W. Liu, Y. R. He, M. Qing, L. R. Zheng, Y. F. Yun, Y. Yang, Y. W. Li, ACS Catal., 2018, 8, 3304-3316.

[11] J. Z. Lu, L. J. Yang, B. L. Xu, Q. Wu, D. Zhang, S. J. Yuan, Y. Zhai, X. Z. Wang, Y. N. Fan, Z. Hu, ACS Catal., 2014, 4, 613-621.

[12] C. Yang, H. B. Zhao, Y. L. Hou, D. Ma, J. Am. Chem. Soc., 2012, 134, 15814-15821.

[13] T. H. Pham, Y. Y. Qi, J. Yang, X. Z. Duan, G. Qian, X. G. Zhou, D. Chen, W. K. Yuan, ACS Catal., 2015, 5, 2203-2208.

[14] T. H. Pham, X. Z. Duan, G. Qian, X. G. Zhou, D. Chen, J. Phys. Chem. C, 2014, 118, 10170-10176.

[15] J. X. Liu, H. Y. Su, D. P. Sun, B. Y. Zhang, W. X. Li, J. Am. Chem. Soc., 2013, 135, 16284-16287.

[16] G. M. Huang, J. Hu, H. Zhang, Z. J. Zhou, X. Q. Chi, J. H. Gao, Nanoscale, 2014, 6, 726-730.

[17] T. A. Wezendonk, V. P. Santos, M. A. Nasalevich, Q. S. E. Warringa, A. I. Dugulan, A. Chojecki, A. C. J. Koeken, M. Ruitenbeek, G. Meima, H. U. Islam, G. Sankar, M. Makkee, F. Kapteijn, J. Gascon, ACS Catal., 2016, 6, 3236-3247.

[18] H. M. T. Galvis, J. H. Bitter, C. B. Khare, M. Ruitenbeek, A. I. Dugulan,
K. P. de Jong, Science, 2012, 335, 835-838.

[19] X. L. Pan, X. H. Bao, Acc. Chem. Res., 2011, 44, 553-562.

[20] X. Q. Chen, D. H. Deng, X. L. Pan, Y. F. Hu, X. H. Bao, Chem. Commun., 2015, 51, 217-220.

[21] W. Chen, Z. L. Fan, X. L. Pan, X. H. Bao, J. Am. Chem. Soc., 2008, 130, 9414-9419.

[22] G. B. Yu, B. Sun, Y. Pei, S. H. Xie, S. R. Yan, M. H. Qiao, K. N. Fan, X. X. Zhang, B. N. Zong, J. Am. Chem. Soc., 2010, 132, 935-937.

[23] X. L. Dong, A. H. Lu, B. He, W. C. Li, J. Power Sources, 2016, 327, 535-542.

[24] Y. Z. Xue, B. Wu, Y. L. Guo, L. P. Huang, L. Jiang, J. Y. Chen, D. C. Geng, Y. Q. Liu, W. P. Hu, G. Yu, Nano Res., 2011, 4, 1208-1214.

[25] L. H. Zhang, Q. Sun, D. H. Liu, A. H. Lu, J. Mater. Chem. A, 2013, 1, 9477-9483.

[26] H. F. Qin, B. Wang, C. Y. Zhang, B. L. Zhu, Y. Zhou, Q. F. Zhou, Catal. Commun., 2017, 96, 28-31.

[27] A. H. Lu, W. C. Li, E. L. Salabas, B. Spliethoff, F. Schüth, Chem. Mater., 2006, 18, 2086-2094.

[28] Z. G. Luo, J. Zhou, X. X. Cao, S. N. Liu, Y. S. Cai, L. R. Wang, A. Q. Pan, S. Q. Liang, Carbon, 2017, 122, 82-91.

[29] M. Oschatz, J. P. Hofmann, T. W. van Deelen, W. S. Lamme, N. A. Krans, E. J. M. Hensen, K. P. de Jong, ChemCatChem, 2017, 9, 620-628.

[30] J. G. Wu, L. C. Wang, B. L. Lv, J. G. Chen, ACS Appl. Mater. Interfaces, 2017, 9, 14319-14327.

[31] N. P. Wickramaratne, J. T. Xu, M. Wang, L. Zhu, L. M. Dai, M. Jaroniec, Chem. Mater., 2014, 26, 2820-2828.

[32] X. H. Gao, J. L. Zhang, N. Chen, Q. X. Ma, S. B. Fan, T. S. Zhao, N. Tsubaki, Chin. J. Catal., 2016, 37, 510-516.

[33] W. Z. Li, Y. L. He, H. J. Li, D. M. Shen, C. Xing, R. Q. Yang, Catal. Commun., 2017, 98, 98-101.

[34] E. Iglesia, S. L. Soled, J. E. Baumgartner, S. C. Reyes, J. Catal., 1995, $153,108-122$.

[35] A. Tavasoli, M. Trépanier, R. M. M. Abbaslou, A. K. Dalai, N. Abatzoglou, Fuel Process. Technol., 2009, 90, 1486-1494.

[36] H. Du, H. J. Zhu, Z. Zhao, W. D. Dong, W. T. Luo, W. Lu, M. Jiang, T. Liu, Y. J. Ding, Appl. Catal. A, 2016, 523, 263-271.

[37] M. Y. Ding, Y. Yang, B. S. Wu, T. J. Wang, L. L. Ma, H. W. Xiang, Y. W. Li, J. Mol. Catal. A, 2011, 351, 165-173.

[38] W. Chen, X. L. Pan, X. H. Bao, J. Am. Chem. Soc., 2007, 129, 7421-7426.

[39] Z. L. Fan, W. Chen, X. L. Pan, X. H. Bao, Catal. Today, 2009, 147, 86-93.

\section{Graphical Abstract}

Chin. J. Catal., 2018, 39: 1971-1979 doi: 10.1016/S1872-2067(18)63158-4

\section{Iron-based catalysts encapsulated by nitrogen-doped graphitic carbon for selective synthesis of liquid fuels through the Fischer-Tropsch process}

Lei Tang, Xiao-Ling Dong, Wei Xu, Lei He, An-Hui Lu* Dalian University of Technology

The catalyst consisting of iron nanoparticles encapsulated by nitrogen-doped graphitic carbon exhibits excellent catalytic activity, high gasoline-range hydrocarbon selectivity, and good stability.

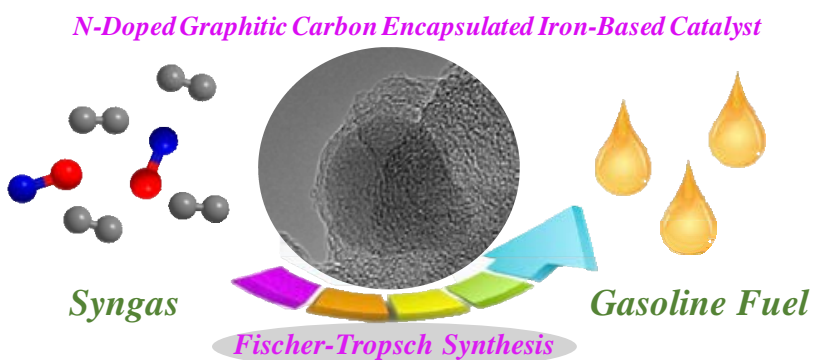


[40] J. K. Norskov, T. Bligaard, B. Hvolbaek, F. Abild-Pedersen, I. Chorkendorff, C. H. Christensen, Chem. Soc. Rev., 2008, 37, 2163-2171.

[41] J. Cheng, P. Hu, P. Ellis, S. French, G. Kelly, C. M. Lok, J. Phys. Chem. C, 2009, 114, 1085-1093.
[42] M. C. Ribeiro, G. Jacobs, R. Pendyala, B. H. Davis, D. C. Cronauer, A. J. Kropf, C. L. Marshall, J. Phys. Chem. C, 2011, 115, 4783-4792.

[43] J. P. Xiao, X. L. Pan, S. J, Guo, P. J. Ren, X. H. Bao, J. Am. Chem. Soc., 2015, 137, 477-482.

\title{
氮掺杂石墨化炭包覆的铁基催化剂的制备及其费托合成反应性能
}

\author{
唐 磊, 董晓玲, 徐薇, 贺 雷, 陆安慧 ${ }^{*}$ \\ 大连理工大学精细化工国家重点实验室, 化工学院, 辽宁大连116024
}

摘要: 由合成气经费托合成(FTS)直接制取液态燃油如汽油 $\left(\mathrm{C}_{5}-\mathrm{C}_{11}\right)$ 或柴油 $\left(\mathrm{C}_{10}-\mathrm{C}_{20}\right)$, 对缓解全球能源危机具有重要意义. 但是, 费托合成产物大多服从Anderson-Schulz-Flory (ASF) 分布, $\mathrm{C}_{5}-\mathrm{C}_{11}$ 烃类选择性最大为 $45 \%$. 因此, 高选择性地合成 $\mathrm{C}_{5}-\mathrm{C}_{11}$ 烃仍具有挑战性. 铁基催化剂价格低廉且能够在较宽温度区间内保持高活性, 其中 $\chi-\mathrm{Fe}_{5} \mathrm{C}_{2}$ 纳米粒子催化剂表现出高 活性及高 $\mathrm{C}_{5}-\mathrm{C}_{11}$ 选择性. 理论计算表明, $\mathrm{Fe}_{5} \mathrm{C}_{2}$ 中高米勒指数晶面如(510)晶面更易暴露, 且C-C偶联反应更易发生在该晶面

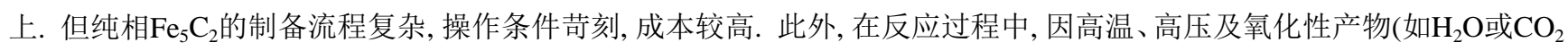
等)的影响, $\mathrm{Fe}_{5} \mathrm{C}_{2}$ 易发生相转变, 导致多物相共存. 因此, 制备在反应过程中能够保持高 $\mathrm{Fe}_{5} \mathrm{C}_{2}$ 含量的催化剂意义重大. 石墨 化炭材料如石墨烯、碳纳米管等, 因其具有大 $\pi$ 电子结构和高电子密度, 作为载体能够促进铁粒子的还原; 氮掺杂石墨化炭 能够进一步改善电子结构, 增强载体与铁物种间的电子传导, 进而促进氧化铁粒子的还原及后续碳化形成 $\mathrm{Fe}_{5} \mathrm{C}_{2}$. 大量研究 表明, 包覆结构具有独特的限域效应, 能够促进碳化铁物相的生成和稳定存在. 结合氮掺杂石墨化炭的电子效应和包覆结 构的限域效应, 有望得到高含量 $\mathrm{Fe}_{5} \mathrm{C}_{2}$ 催化剂, 实现高 $\mathrm{C}_{5}-\mathrm{C}_{11}$ 选择性. 因此, 本文通过谷氨酸与 $\mathrm{Fe}$ 物种的配位作用, 合成Fe高 度分散的配合物, 并热解得到氮掺杂石墨化炭包覆铁基催化剂 $\left(\mathrm{FeC}-x, x\right.$ 为热解温度 $\left({ }^{\circ} \mathrm{C}\right)$ ), 通过改变热解温度调变炭层结构, 并考察了其对催化剂费托性能的影响.

在不同热解温度下制备的催化剂的费托合成反应结果表明, FeC-800催化活性高达 $239.4 \mu \mathrm{mol}_{\mathrm{CO}} \mathrm{g}_{\mathrm{Fe}}^{-1} \mathrm{~s}^{-1}$, 分别是 $\mathrm{FeC}-700$ 的 2 倍和FeC-900的 20 倍. 而且, FeC-800的 $\mathrm{C}_{5}-\mathrm{C}_{11}$ 烃类选择性为 $49 \%$, 高于大多数报道的 $\mathrm{Fe} / \mathrm{C}$ 催化剂. FeC-900则表 现出较低的 $\mathrm{C}_{5}-\mathrm{C}_{11}$ 烃类选择性. $\mathrm{TG}$ 表征发现, 热解温度升高, 炭层石墨化过程中有损失, 导致实际铁负载量增高. XRD和 Raman结果表明, 炭层石墨化程度随热解温度升高而增加. $\mathrm{N}_{2}$ 吸附-脱附等温线表明催化剂存在介孔, 有利于反应物及产物 的扩散. TEM观察到铁纳米粒子被包覆在石墨化炭结构中. XPS测试结果显示, 催化剂表面可探测到的元素为C, O, N和 Fe. 其中表面Fe的含量远低于实际负载量, 说明铁纳米粒子大多存在于包覆炭层之内. 通过对比反应 $60 \mathrm{~h}$ 前后样品的TEM 结果发现, 催化剂铁纳米粒子尺寸无明显增加, 说明炭层对铁纳米粒子具有限域作用. 炭层的包覆可能对产物选择性造成 影响: 一方面, 炭层能够抑制烯烃的扩散, 促进二次反应, 从而促进长链烃的生成; 另一方面, 炭层的空间效应也会抑制更 长链烃(如 $\mathrm{C}_{12+}$ ) 的生成. 因此, $\mathrm{FeC}-800$ 表现出高 $\mathrm{C}_{5}-\mathrm{C}_{11}$ 选择性. 通过 $\mathrm{N} 1 s$ 谱图可以发现, 石墨化氮、吡啶氮及吡咯氮是主要 的表面氮物种, 说明 $\mathrm{N}$ 被成功掺杂进石墨化炭结构中. 且随热解温度增加, 石墨化氮含量增加. 通过 $\mathrm{H}_{2}-\mathrm{TPR}$ 及还原后XRD 结果发现, $\mathrm{FeC}-700$ 与 $\mathrm{FeC}-800$ 具有较低的还原温度, 易被 $\mathrm{H}_{2}$ 还原为单质 $\mathrm{Fe}$, 这有利于在反应过程中转变为活性相 $\mathrm{Fe}_{5} \mathrm{C}_{2}$. CO-TPD结果显示, CO吸附强度随样品热解温度升高而显著增加. 热解温度的提高促进了炭层的石墨化度, 强化了炭层与 $\mathrm{Fe}$ 之间的电子转移, 进而增强了 $\mathrm{Fe}$ 与 $\mathrm{CO}$ 间的相互作用, 促进了 $\mathrm{H}_{2}$ 还原后生成的单质 $\mathrm{Fe}$ 碳化为 $\mathrm{Fe}_{5} \mathrm{C}_{2}$, 并且 $\mathrm{Fe}_{5} \mathrm{C}_{2}$ 在反应过程 中不易被氧化. 高含量的 $\mathrm{Fe}_{5} \mathrm{C}_{2}$ 和适宜的 $\mathrm{CO}$ 吸附强度使 $\mathrm{FeC}-800$ 催化剂表现出高催化活性及高 $\mathrm{C}_{5}-\mathrm{C}_{11}$ 选择性.

关键词: 氮掺杂; 石墨化炭; 包裹结构; 铁基催化剂; 费托合成

收稿日期: 2018-07-30. 接受日期: 2018-08-16. 出版日期: 2018-12-05.

*通讯联系人. 电话/传真: (0411)84986112; 电子信箱: anhuilu@dlut.edu.cn

基金来源：国家自然科学基金(21733002, 21506077); 长江学者奖励计划(T2015036).

本文的电子版全文由Elsevier出版社在ScienceDirect上出版(http://www.sciencedirect.com/science/journal/18722067). 